\title{
Oyster growth across a salinity gradient in a shallow, subtropical Gulf of Mexico estuary ${ }^{\dagger}$
}

\author{
Benoit Lebreton ${ }^{1,2, *}$, Jennifer Beseres Pollack ${ }^{1}$ (D), Brittany Blomberg ${ }^{1}$, Terence A. Palmer ${ }^{1}$ (D) and \\ Paul A. Montagna ${ }^{1}$ \\ ${ }^{1}$ Harte Research Institute for Gulf of Mexico Studies, Texas A\&M University - Corpus Christi, 6300 Ocean Drive, Unit 5869, \\ Corpus Christi, TX 78412-5869, USA, and ${ }^{2}$ UMR Littoral, Environment et Societies (CNRS - University of La Rochelle), Institut \\ du Littoral et de l'Environnement, 2 rue Olympe de Gouges, 17000 La Rochelle, France \\ ${ }^{\star}$ Corresponding author. Email address: benoit.lebreton@univ-lr.fr
}

(Received 05 November 2020; Revised 23 December 2020; Accepted 23 December 2020)

\begin{abstract}
An increase in oyster aquaculture as a sustainable method of shellfish production is one response to overharvest and degradation of natural oyster reefs over the past century. Successful aquaculture production requires determining the environmental conditions optimal for oyster growth. In this study, the salinity, temperature, chlorophyll a concentration and the growth of Crassostrea virginica were monitored at four locations within the Mission-Aransas Estuary, Texas (USA), a shallow subtropical estuary influenced by relatively low freshwater inflow. Mean growth of the oyster shell $\left(0.205 \mathrm{~mm} \mathrm{~d}^{-1}\right.$ and $\left.0.203 \mathrm{~g} \mathrm{~d}^{-1}\right)$ and soft tissues $\left(3.447 \mathrm{mg} \mathrm{d}^{-1}\right)$ was highest when salinity was low (mean $\left.=15.5\right)$ and chlorophyll $a$ concentration was high $\left(8.4 \mu \mathrm{gl}^{-1}\right)$. Oyster growth also varied temporally with periods of spawning. In low-inflow estuaries such as the Mission-Aransas Estuary, oyster farms should be sited close to river mouths so that oysters can benefit from freshwater inflows and lower salinities.
\end{abstract}

Keywords: Crassostrea virginica; Gulf of Mexico; salinity; chlorophyll $a$; oyster farming

\section{Introduction}

Oyster reefs provide a variety of ecological functions, from creating habitat for a large diversity of species to protecting shorelines against erosion (Grabowski et al., 2012). Oysters are also harvested by humans, and therefore directly support local economies (Lebreton et al., 2019). A major issue related to oyster fisheries, particularly those using dredges, is that they can lead to the destruction of the oyster reefs themselves, impeding their longevity and resulting in the loss of ecological functions (Kirby, 2012). A more sustainable way of providing oysters to the market is to farm these animals, an established practice in many locations (e.g., Chesapeake Bay, USA; France) to stabilize oyster production and reduce harvest pressure on wild populations (Lebreton et al., 2019; Williamson et al., 2015). In the United States, Texas was the last coastal state to pass legislation (in 2019) to allow oyster farming in the U.S. Gulf of Mexico, with commercial farming activities scheduled to begin in late 2020. Oyster aquaculture includes hatchery-based production of seed oysters followed by field-based maturation of oysters to market size to benefit from natural food resources and favorable environmental conditions. Oyster growth is related to many environmental

\footnotetext{
${ }^{\dagger}$ Jennifer Beseres Pollack's name was incorrectly given in the original article. This has been corrected and an erratum notice was also published.

(c) The Author(s), 2021. Published by Cambridge University Press. This is an Open Access article, distributed under the terms of the Creative Commons Attribution licence (http://creativecommons.org/licenses/by/4.0), which permits unrestricted re- use, distribution and reproduction, provided the original article is properly cited.
} 
variables (e.g., food availability, salinity, temperature) as well as to oysters' ontogeny (see Kraeuter et al., 2007). To support oyster farming activities-particularly in areas where aquaculture has not previously existed-it is important to determine suitable conditions and locations for optimal oyster growth.

\subsection{Objective}

Our aim was to determine spatio-temporal changes in shell and soft tissue growth of the oyster Crassostrea virginica in the Mission-Aransas Estuary (MAE), Texas, USA, and to relate these changes to spatial differences in salinity, temperature and chlorophyll $a$ concentration.

\section{Methods}

The MAE is a subtropical, shallow (mean $=2 \mathrm{~m}$ deep), bar-built estuary. This estuarine ecosystem was chosen as a study area because it contains abundant natural oyster reefs relative to other Texas estuaries ( 1811 ha of natural, subtidal oyster reefs, Beseres Pollack et al., 2013), indicating suitable environmental conditions for oyster growth. The MAE has a typical salinity gradient, with lower salinities occurring near the mouth of the largest rivers that flow into the estuary (Mission and Aransas Rivers) and higher salinities toward the Gulf of Mexico (Fig. 1). Oyster reefs throughout most of the MAE are open to commercial harvest and thus susceptible to habitat degradation, although some areas have been rebuilt through habitat restoration efforts (Blomberg et al., 2017; Graham et al., 2016; Rezek et al., 2017).

Seed oysters were placed in UV-resistant polyethylene mesh bags at four different stations along the salinity gradient of the MAE (Fig. 1). Each bag $(80 \times 50 \mathrm{~cm}, 1 \mathrm{~cm}$ mesh) contained 100 seed oysters (shell height $49.4 \pm 7.2 \mathrm{~mm}$, shell dry weight $8.2 \pm 2.2 \mathrm{~g}$, soft tissue dry weight $0.2 \pm 0.1 \mathrm{~g}$, mean \pm standard deviation) and was mounted horizontally at approximately $50-100 \mathrm{~cm}$ from the sediment. At monthly intervals from November 2010 to August 2011, which includes the typical spawning period, ten oysters were collected from each station and water salinity and temperature were measured. A water sample was also collected, pre-filtered on a $250-\mu \mathrm{m}$ sieve to eliminate large zooplankton and detritus, and then filtered on a Whatman GF/F glass fiber filter ( $0.7 \mu \mathrm{m}$ porosity) to measure chlorophyll $a$ concentration.

In the laboratory, oysters were rinsed clean, measured with a caliper $( \pm 0.01 \mathrm{~mm})$, and then dissected to separate the soft tissue from the shell. Gonad presence was determined visually. Shells and soft tissues were dried for 72 hours at $60^{\circ} \mathrm{C}$ before measuring dry weights ( $\pm 0.001 \mathrm{~g}$ ). Chlorophyll $a$ was extracted

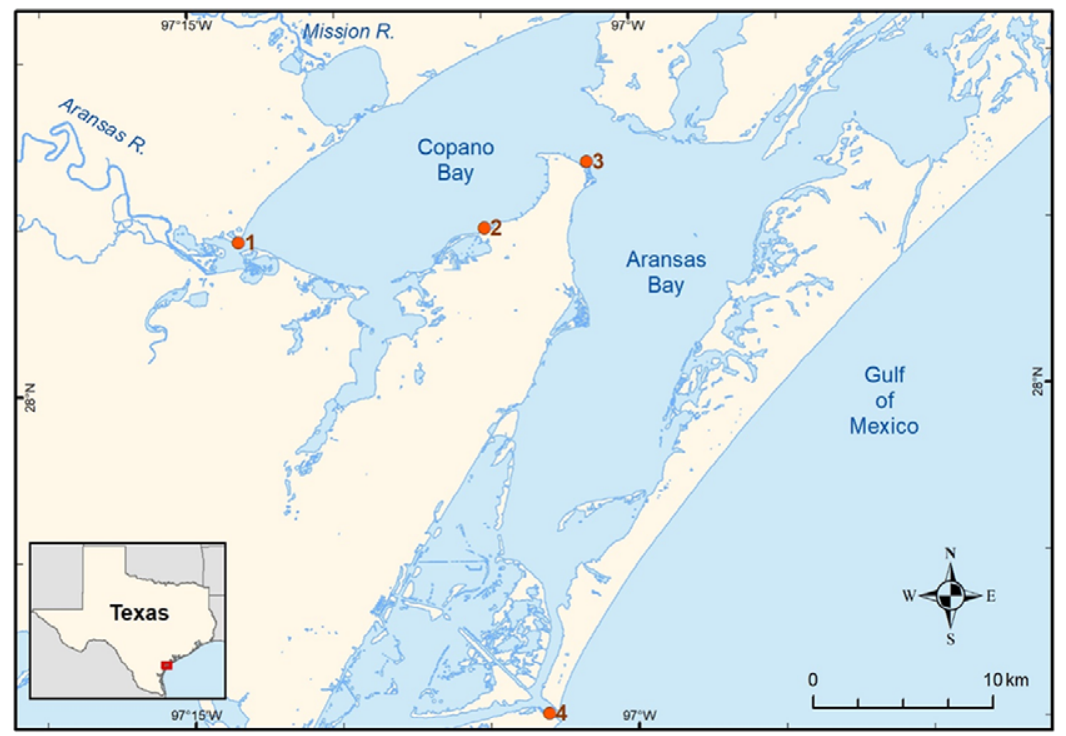

Figure 1. Location of the experimental stations within the Mission-Aransas Estuary. 

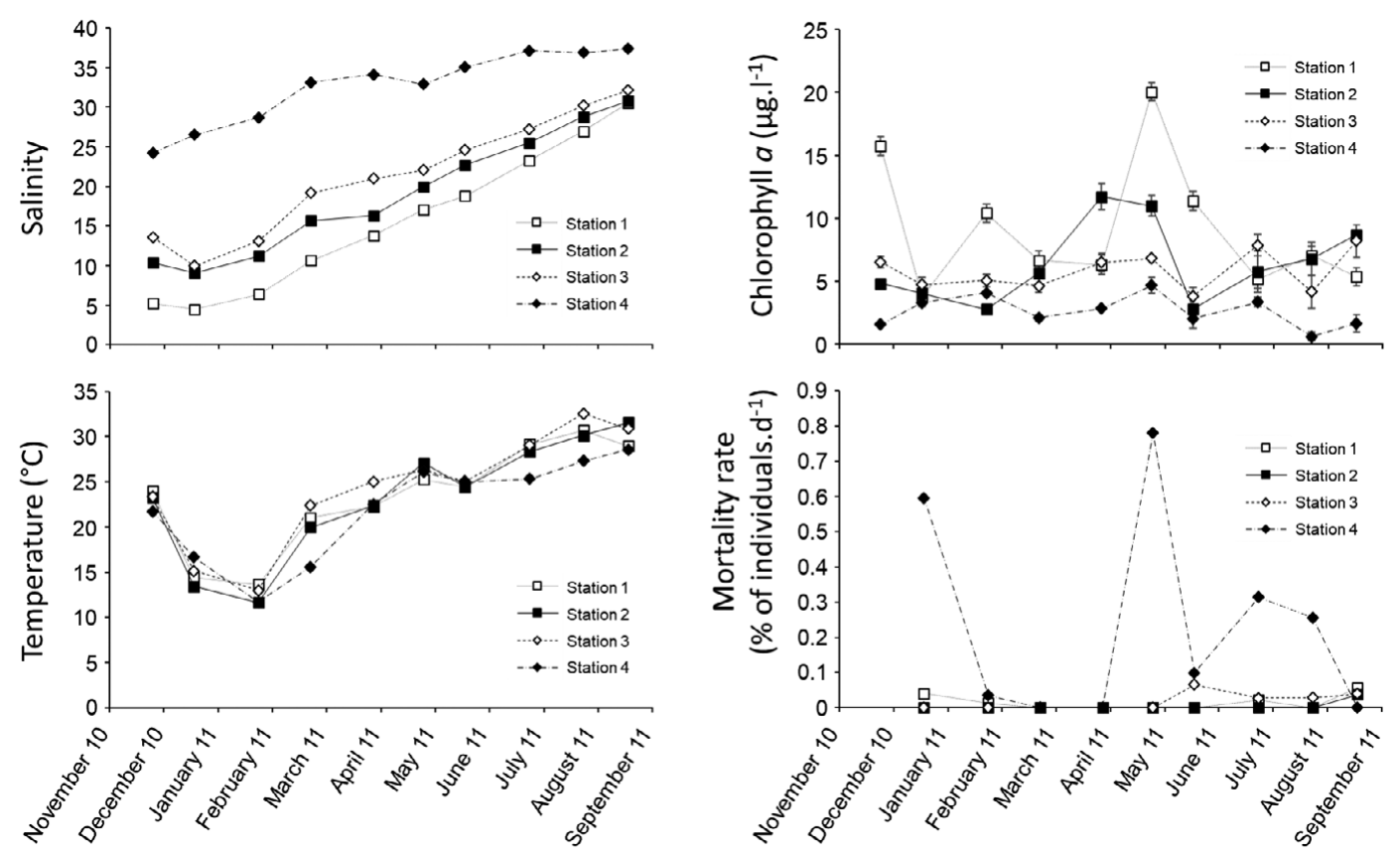

Figure 2. Salinity, temperature, mean chlorophyll $a$ and mortality rate at the different experimental stations from November 2010 to August 2011. Error bars represent standard deviations of mean chlorophyll $a$.

overnight from filters and read on a fluorometer (Trilogy, Turner Designs, Sunnyvale, USA) using a nonacidification technique (Welschmeyer, 1994). Comparisons of means were conducted using KruskalWallis tests followed by multiple pairwise-comparisons unless otherwise specified.

\section{Results}

Salinity generally increased from station 1 to station 4, and from the beginning to the end of the study period (Fig. 2). Salinity ranged from 4.5 at station 1 in December 2010 to 37.4 at station 4 in August 2011 at the end of the study. Temperature followed expected seasonal variation in all stations, and was higher at station $3\left(24.3 \pm 6.3^{\circ} \mathrm{C}\right)$ than at station $4\left(22.1 \pm 5.6^{\circ} \mathrm{C}\right)(p=0.045$, Friedman test followed by Nemenyi multiple comparison tests). Chlorophyll $a$ concentration ranged from $1.0 \pm 0.4$ (Station 4, July 2011 ) to $20.0 \pm 2.2 \mu \mathrm{g} \mathrm{l}^{-1}$ (Station 1, April 2011) and was lower at station 4 compared to all other stations $(p=0.001$, Friedman test followed by Nemenyi multiple comparison tests).

Oyster mortality rates were low at stations 1 to 3 (i.e., maximum $0.07 \%$ per day at station 3 in May 2010) but were much higher and much more variable at station 4 near the Gulf of Mexico where they ranged from 0.00 to $0.78 \%$ per day (Fig. 2). Shell height and weight at each station generally increased throughout the study period (Fig. 3). Conversely, soft tissue weight varied over time, with the largest increases and decreases corresponding to changes in gonadal maturation. At the end of the study in August 2011, shell height and shell weights were lower at station $4(70.9 \pm 5.4 \mathrm{~mm}, 37.1 \pm 5.3 \mathrm{~g})$, closest to the Gulf of Mexico, than at stations 1 and 3 (Height: $83.1 \pm 9.0 \mathrm{~mm}$ and $83.6 \pm 8.3 \mathrm{~mm}$, respectively, $p=0.010$; weight: $60.0 \pm 5.8 \mathrm{~g}$ and $56.5 \pm 11.6 \mathrm{~g}$, respectively, $p<0.001)$. Similarly, maximum soft tissue weights-excluding periods of gonad maturation-were lower at station 4 (0.5 $\pm 0.1 \mathrm{~g}$, August 2011), than at stations 1 and $3(0.9 \pm 0.2 \mathrm{~g}$ and $0.7 \pm 0.2 \mathrm{~g}$, June 2011 , respectively, $p<0.001)$. Relationships between shell height, shell weight and tissue weight varied by station (Fig. 4). Maximum shell heights observed at stations $1,2,3$ and 4 were $91.3 \pm 5.3 \mathrm{~mm}, 82.8 \pm 8.0 \mathrm{~mm}, 83.6 \pm 8.3 \mathrm{~mm}$, and $76.8 \pm 5.5 \mathrm{~mm}$, respectively. 

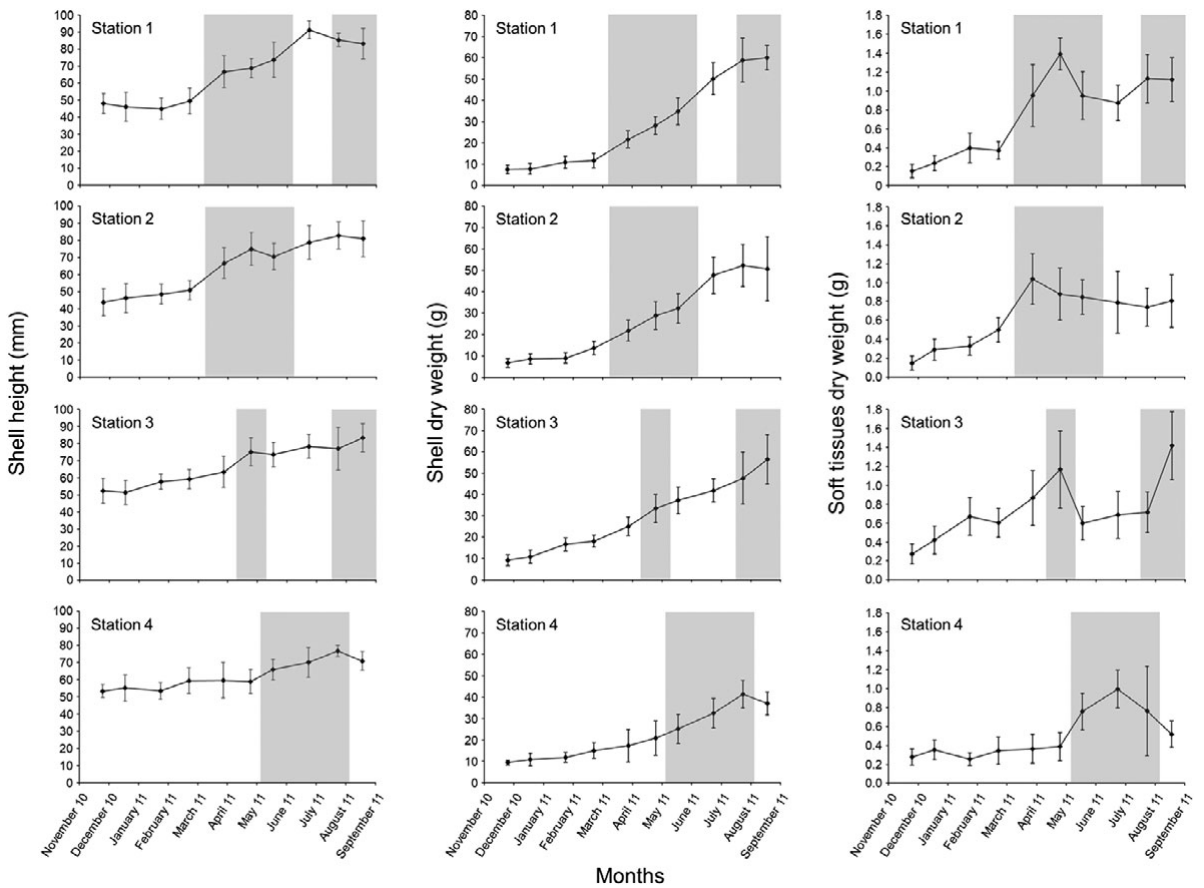

Figure 3. Evolution of shell height, and shell and soft tissue dry weights (mean \pm standard deviation) at the different experimental stations from November 2010 to August 2011. Grey shaded areas represent periods of gonad maturation.
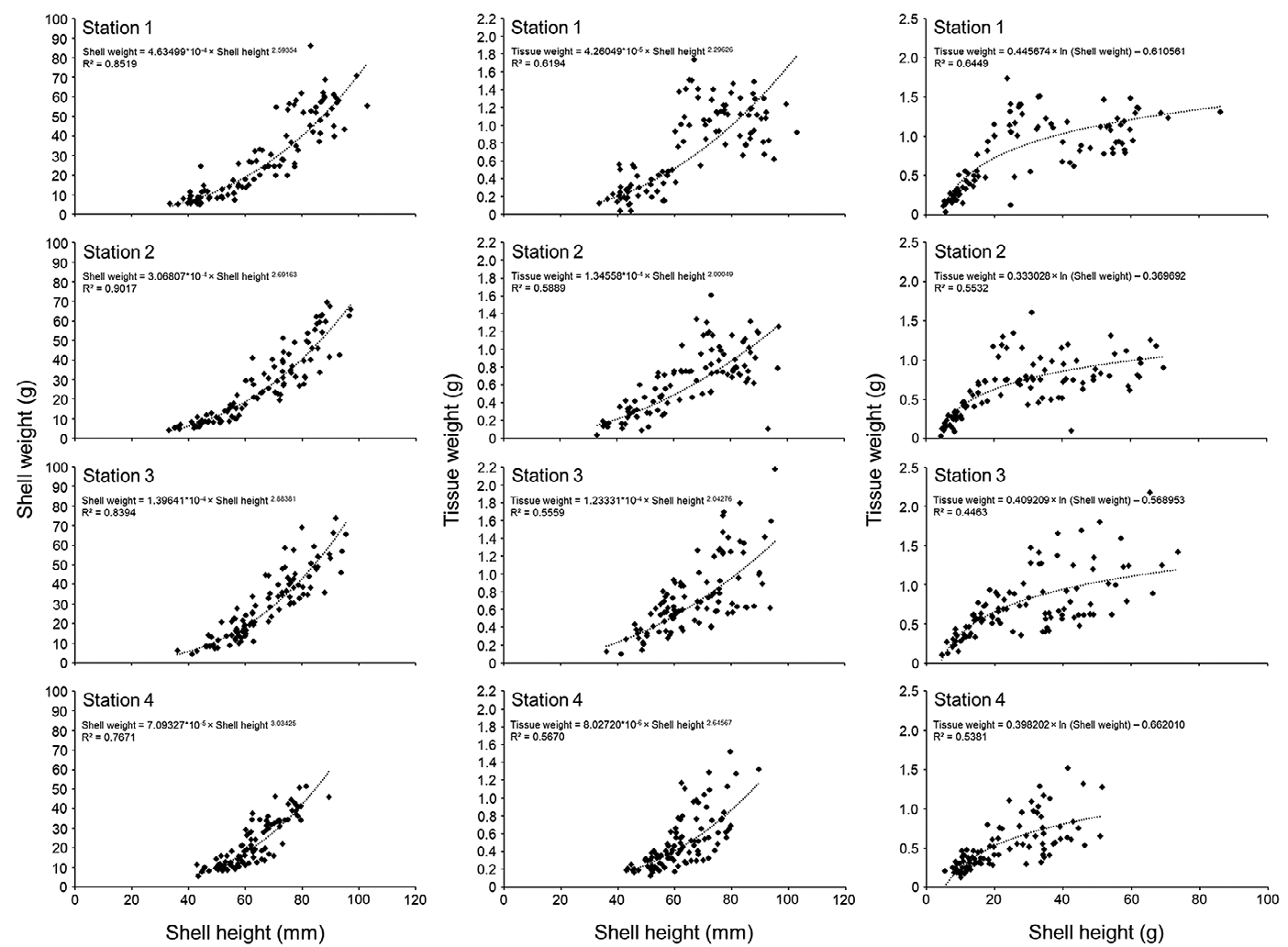

Figure 4. Relationships between shell height, shell weight and tissue weight of Crassostrea virginica at the four sampling stations in the Mission-Aransas estuary, USA. Averaged salinities: Station 1: 15.5; Station 2: 18.9; Station 3: 21.1; Station 4: 32.2. 

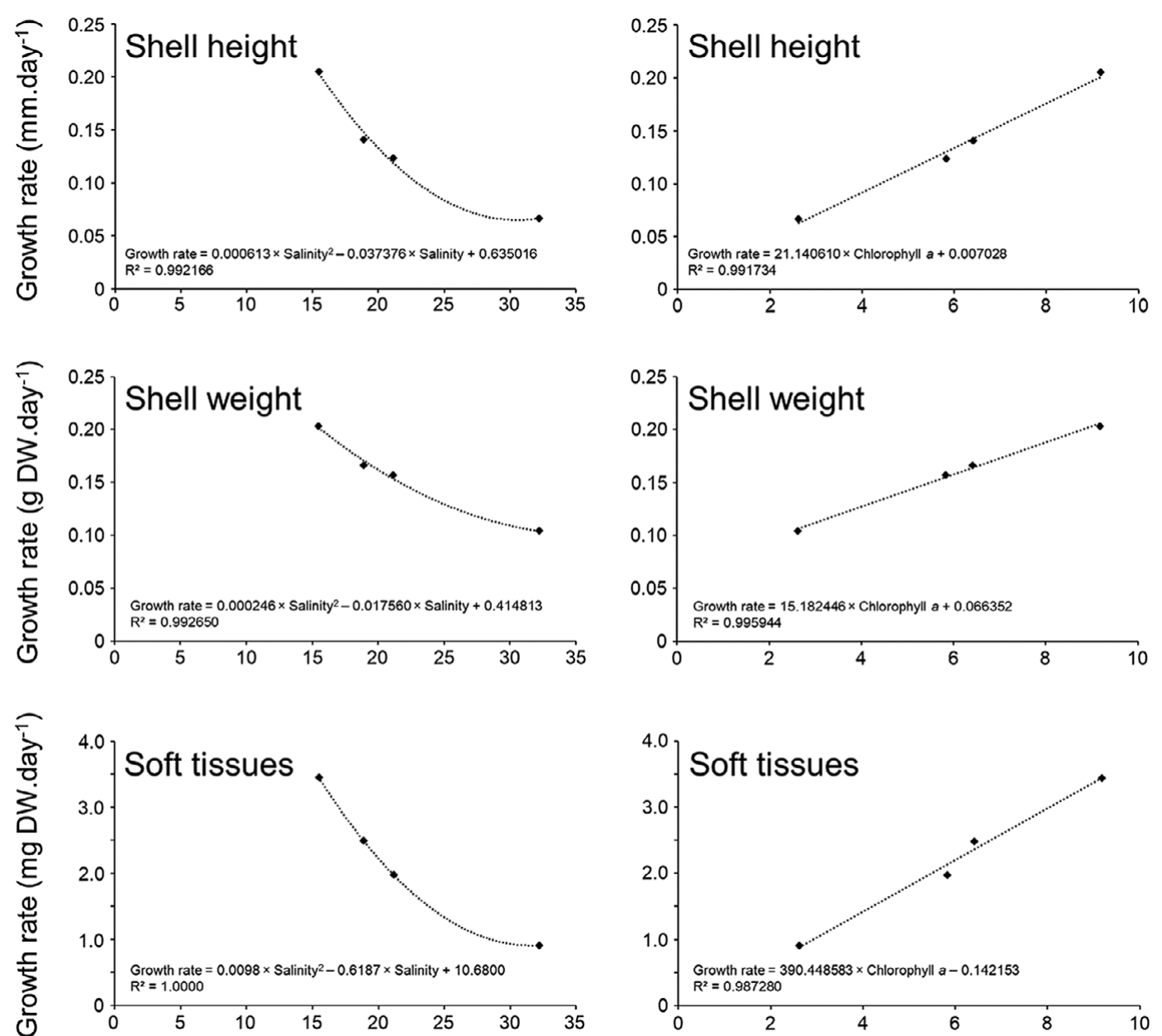

Averaged salinity

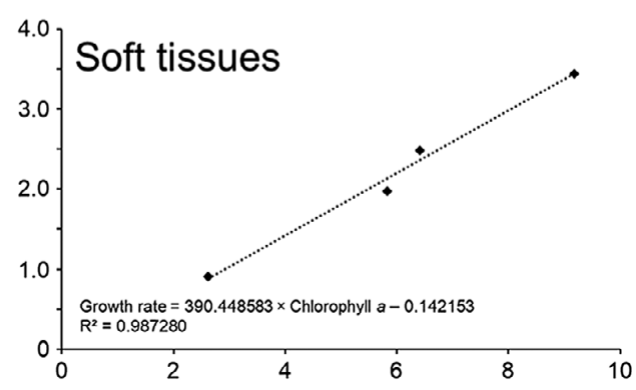

Averaged chlorophyll a $\left(\mu \mathrm{g} . \mathrm{I}^{-1}\right)$

Figure 5. Relationships between averaged salinity and averaged chlorophyll $a$ concentration, and growth rates of shells and soft tissues. Periods of gonad maturation were excluded for computations (i.e. periods considered started in November 2010 for all stations and ended in June 2011 for stations 1 and 3, and in August 2011 for stations 2 and 4). DW: Dry weight.

Two periods of gonad maturation occurred at stations 1 and 3, while only one was observed at stations 2 and 4 (Fig. 3). Initial gonad maturation occurred later at station 4 (i.e., May) than at the other stations (i.e., March-April). Soft tissue weights peaked within gonadal maturation periods at each station, with maximum values ranging from $1.0 \pm 0.2 \mathrm{~g}$ (Station 4 , June 2011) to $1.4 \pm 0.4 \mathrm{~g}$ (Station 3, August 2011).

When gonads were immature, mean growth rates of shell and soft tissue at each station were inversely related to mean salinities, and positively related to chlorophyll $a$ concentration (Fig. 5). Mean shell growth rates ranged from $0.104 \mathrm{mg} \mathrm{d}^{-1}$ (dry shell weight) and $0.07 \mathrm{~mm} \mathrm{~d}^{-1}$ (shell height) at station 4 near the Gulf of Mexico (mean salinity 32.3, mean chlorophyll $a 2.6 \mu \mathrm{gl}^{-1}$ ) to $0.203 \mathrm{mg} \mathrm{d}^{-1}$ and $0.205 \mathrm{~mm} \mathrm{~d}^{-1}$ at station 1 near the Aransas River (mean salinity 15.5, mean chlorophyll $a 9.2 \mu \mathrm{gl}^{-1}$ ). Mean tissue growth rates ranged from $0.910 \mathrm{mg} \mathrm{d}^{-1}$ at station 4 to $3.447 \mathrm{mg} \mathrm{d}^{-1}$ at station 1 . 


\section{Discussion}

The largest differences in overall growth rate occurred spatially, although oyster growth also displayed temporal variation with periods of spawning. Differences in growth rates were likely due to differences in salinity and chlorophyll $a$ concentration, as variations in temperature were minor between stations. Oyster growth rate was much higher at station 1, near the Aransas River, which had the lowest salinity and high phytoplankton biomass, as evidenced by chlorophyll $a$ concentration (shell growth rate: $0.205 \mathrm{~mm} \mathrm{~d}^{-1}$, mean salinity: 15.5 , mean chlorophyll $a$ concentration: $9.2 \mu \mathrm{g} \mathrm{l}^{-1}$ ).

We compared oyster growth rates from our study with those measured in other locations across the U.S. Atlantic and Gulf of Mexico (reviewed by Kraeuter et al., 2007). Growth rates measured at stations 1 to 3 in the current study (i.e., from 3.77 to $6.26 \mathrm{~mm} \mathrm{month}^{-1}$ ) are among the highest reported, with values above the upper quartile of growth rates for oysters $>40 \mathrm{~mm}$ deployed in the field for less than 10 months (1.82 $\mathrm{mm} \mathrm{month}^{-1}$ for the East coast, $2.94 \mathrm{~mm} \mathrm{month}^{-1}$ for the Gulf of Mexico). Growth rates measured in the MAE are within in the range of those measured in Louisiana by Lowe et al. (2017) for oysters of a similar size range.

\section{Conclusions}

Oyster aquaculture areas in subtropical, low-inflow estuaries should be located in areas with the lowest salinity and highest phytoplankton biomass to obtain the best growth rates. Because variations in the timing and frequency of gonad maturation also differed spatially-likely due to differences in salinityoyster aquaculture areas could also be sited at different locations in order to produce oysters throughout the year for market. Additional research is warranted to better assess the importance of salinity and phytoplankton biomass in oyster growth, as well as other factors like availability and quality of food resources (e.g., role of phytoplankton $v$ s benthic microalgae) (Blomberg et al., 2017) and presence of natural reefs to inform oyster farm site selection.

Acknowledgements. We are grateful to R. Kalke, M. Besonen, S. Arismendez, D. Yoskowitz, P. Richard and G. Blanchard for their helpful advice and support. We would also like to thank G. Wise who allowed us to use his property, E. Morgan, A. Lord, C. Santos, L. Hutchison, K. Welder, B. Paudel, L. Hyde, D. Mangold, E. Chalkley, C. Taylor, M. Proffitt, E. Buschfort, C. Hampton, C. Carollo, M. Barajas for their invaluable help during collection and preparation of samples, and G. Sutton, L. Eckert and A. Knight for their support in administrative tasks. We also thank the three reviewers for their helpful comments.

Author contributions. BL and PAM conceived and designed the study. BL, BB, TP and JBP conducted data collection. BL performed statistical analyses. BL and JBP wrote the article. Authors have no conflict of interest.

Funding information. This study was funded partially by a postdoctoral research grant from the Conseil Général of Charente Maritime in France, and partially by the Harte Research Institute for Gulf of Mexico Studies.

Data availability. Data used in this paper are available at the Gulf of Mexico Research Initiative Information and Data Cooperative (GRIIDC, Lebreton 2020).

\section{References}

Beseres Pollack, J., Yoskowitz, D., Kim, H.-C., \& Montagna, P. A. (2013). Role and value of nitrogen regulation provided by oysters (Crassostrea virginica) in the Mission-Aransas Estuary, Texas, USA. PLoS ONE, 8, e65314. doi: https://doi. org/10.1371/journal.pone.0065314.

Blomberg, B. N., Lebreton, B., Palmer, T. A., Guillou, G., Beseres Pollack, J., \& Montagna, P. A. (2017). Does reef structure affect oyster food resources? A stable isotope assessment. Marine Environmental Research, 127, 32-40. doi: https://doi. org/10.1016/j.marenvres.2017.03.003.

Grabowski, J. H., Brumbaugh, R. D., Conrad, R. F., Keeler, A. G., Opaluch, J. J., Peterson, C. H., Piehler, M. F., Powers, S. P., \& Smyth, A. R. (2012). Economic valuation of ecosystem services provided by oyster reefs. Bioscience, 62, 900-909. doi: https://doi.org/10.1525/bio.2012.62.10.10.

Graham, P., Palmer, T. A., \& Beseres Pollack, J. (2016). Oyster reef restoration: Substrate suitability may depend on specific restoration goals. Restoration Ecology, 25, 459-470. doi: https://doi.org/10.1111/rec.12449. 
Kirby, M. X. (2012). Fishing down the coast: Historical expansion and collapse of oyster fisheries along continental margins. Proceedings of the National Academy of Sciences of the United States of America, 101, 13096-13099. doi: https://doi. org/10.1073/pnas.0405150101.

Kraeuter, J. N., Ford, S., \& Cummings, M. (2007). Oyster growth analysis: A comparison of methods. Journal of Shellfish Research, 26, 479-491. doi: https://doi.org/10.2983/0730-8000(2007)26[479:OGAACO]2.0.CO;2.

Lebreton, B., Beseres Pollack, J., Blomberg, B., Palmer, T. A., \& Montagna, P. A. (2020). Oyster growth in a shallow subtropical estuary (Mission-Aransas Estuary, Texas, USA). Distributed by: Gulf of Mexico Research Initiative Information and Data Cooperative (GRIIDC), Harte Research Institute, Texas A\&M University-Corpus Christi. https://doi.org/10.7266/ AC120KMV

Lebreton, B., Rivaud, A., Picot, L., Prévost, B., Barillé, L., Sauzeau, T., Beseres Pollack, J., \& Lavaud, J. (2019). From ecological relevance of the ecosystem services concept to its sociopolitical use. The case study of intertidal bare mudflats in the Marennes-Oléron Bay, France. Ocean \& Coastal Management, 172, 41-54. doi: https://doi.org/10.1016/j.ocecoaman.2019.01.024.

Lowe, M. R., Sehlinger, T., Soniat, T. M., \& La Peyre, M. K. (2017). Interactive effects of water temperature and salinity on growth and mortality of eastern oysters, Crassostrea virginica: A meta-analysis using 40 years of monitoring data. Journal of Shellfish Research, 36, 683-697. doi: https://doi.org/10.2983/035.036.0318.

Rezek, R. J., Lebreton, B., Roark, E. B., Palmer, T. A., \& Beseres Pollack, J. (2017). How does a restored oyster reef develop? An assessment based on stable isotopes and community metrics. Marine Biology, 164, 54. doi: https://doi.org/10.1007/ s00227-017-3084-2.

Welschmeyer, N. A. (1994). Fluorometric analysis of chlorophyll $a$ in the presence of chlorophyll $b$ and pheopigments. Limnology and Oceanography, 39, 1985-1992. doi: https://doi.org/10.4319/lo.1994.39.8.1985.

Williamson, T. R., Tilley, D. R., \& Campbell, E. (2015). Emergy analysis to evaluate the sustainability of two oyster aquaculture systems in the Chesapeake Bay. Ecological Engineering, 85, 103-120. doi: https://doi.org/10.1016/j.ecoleng.2015.09.052.

Cite this article: Lebreton B, Beseres Pollack J, Blomberg B, Palmer TA, Montagna PA (2021). Oyster growth across a salinity gradient in a shallow, subtropical Gulf of Mexico estuary Experimental Results, 2, e10, 1-12. https://doi.org/10.1017/exp.2020.72 


\section{Peer Reviews}

\section{Reviewing editor: Dr. Michael Nevels}

University of St Andrews, Biomolecular Sciences Building, Fife, United Kingdom of Great Britain and Northern Ireland, KY16 9ST

This article has been accepted because it is deemed to be scientifically sound, has the correct controls, has appropriate methodology and is statistically valid, and has been sent for additional statistical evaluation and met required revisions.

doi:10.1017/exp.2020.72.pr1

Review 1: Oyster growth in a shallow, subtropical Gulf of Mexico estuary

Reviewer: Dr. Stephen G. Hesterberg (iD

University of South Florida, Department of Integrative Biology, 4202 E Fowler Ave, Tampa, Florida, United States, 33620-9951

Date of review: 07 December 2020

(C) The Author(s), 2021. Published by Cambridge University Press This is an Open Access article, distributed under the terms of the Creative Commons Attribution licence (http://creativecommons.org/licenses/by/4.0), which permits unrestricted re- use, distribution and reproduction, provided the original article is properly cited.

Conflict of interest statement. I have no conflicts of interest.

Comments to the Author: I have read the manuscript by Benoit et al. (EXP-20-0099) and find it well within the standards put forth by Experimental Results for publication. The study provides a note on oyster growth and reproduction in the Mission-Aransas Estuary from 2010-2011. Overall, the research puts forth useful baseline data that can be used to compare with future studies of oyster ecology in the Gulf of Mexico. It also contains helpful information for local managers and oyster producers.

A couple suggestions to improve the manuscript:

(1) The title could be more informative. For instance, the abstract identifies MAE as a rather high salinity estuary. Since there are strong connections to salinity made in the manuscript, I recommend replacing "shallow" with something reflecting this more pertinent environmental context.

(2) Maximum shell height is a under reported metric in studies of oyster size. I recommend adding a sentence in the results section reporting maximum size observed at all stations at the end of the study. This information could be pertinent for future comparisons.

(3) Citation formatting should be double checked. For example, spacing issues occur in lines 169 and 172. Also, in line 189, the title reads "Emergy" which I assume should be "Energy."

\section{Score Card}

Presentation 
Does the abstract correctly embody the content of the article? (25\%)

Does the introduction give appropriate context? (25\%)

Is the objective of the experiment clearly defined? (25\%)

Analysis

Does the discussion adequately interpret the results presented? (40\%)

Is the conclusion consistent with the results and discussion? (40\%)

Are the limitations of the experiment as well as the contributions of the experiment clearly outlined? $(20 \%)$ 


\title{
Review 2: Oyster growth in a shallow, subtropical Gulf of Mexico estuary
}

\author{
Reviewer: Dr. Gulnihal Ozbay ${ }^{1,2}$ if \\ ${ }^{1}$ Delaware State University College of Agriculture and Related Sciences, Agriculture and Natural Resources, 1200 North DuPont \\ Highway, Dover, Delaware, United States, 19901, 1+ (302) 8576402 \\ ${ }^{2}$ Delaware State University, 1200 North DuPont Highway, 1200 North DuPont Highway Dover, Delaware, United States, 19901
}

Date of review: 10 December 2020

\begin{abstract}
(C) The Author(s), 2021. Published by Cambridge University Press This is an Open Access article, distributed under the terms of the Creative Commons Attribution licence (http://creativecommons.org/licenses/by/4.0), which permits unrestricted re- use, distribution and reproduction, provided the original article is properly cited.
\end{abstract}

Conflict of interest statement. None

Comments to the Author: Information provided in this manuscript new and may serve as a good foundation for the potential oyster aquaculture industry. Although water quality monitoring is limited to temperature and salinity, oyster growth characteristics clearly are showing better oyster growth at low salinity areas. It might have been really helpful to the authors to further interpret their research outcomes if they had chlorophyll and total suspended solids data. Authors will feel more comfortable stating that salinity is the primary effect on oyster growth in those areas. The authors showed 4 stations but in the methods, they mentioned station 5 which is not on the map. Also, the authors did not state if they had any control in their study. There seems to be only 1 station in Aransas Bay compared to Copano Bay. Authors need to provide further details on their experimental approach if they used control. How frequently they measured oysters and how many oysters each time. What presented in this manuscript deserves sharing, however, it has the limitation with the experimental approach, method details, and data outcomes. Perhaps, authors provide further details on this study to clarify a few shortfalls or they publish their research as a short communication article or Research Notes. This article needs some revision. Line 87 , station 5 ? Is this control? No station 5 on the map. Figure 2 is confusing. Perhaps, authors use different shape and dotted lines for data from various stations.

\section{Score Card}

Presentation

\section{7}

Is the article written in clear and proper English? (30\%)

Is the data presented in the most useful manner? (40\%)

Does the paper cite relevant and related articles appropriately? (30\%)

\section{Context}

Does the title suitably represent the article? (25\%)

Does the abstract correctly embody the content of the article? (25\%)

Does the introduction give appropriate context? (25\%)

Is the objective of the experiment clearly defined? $(25 \%)$ 
Are the limitations of the experiment as well as the contributions of the experiment clearly outlined? (20\%) 


\section{Review 3: Oyster growth in a shallow, subtropical Gulf of Mexico estuary}

Reviewer: Dr. William Walton iD

Auburn University, United States

Date of review: 13 December 2020

(C) The Author(s), 2021. Published by Cambridge University Press This is an Open Access article, distributed under the terms of the Creative Commons Attribution licence (http://creativecommons.org/licenses/by/4.0), which permits unrestricted re- use, distribution and reproduction, provided the original article is properly cited.

Conflict of interest statement. Reviewer declares none

Comments to the Author: The results presented here are useful and worth publishing. The discussion, however, gives too much weight to salinity as the explanatory factor for the observed differences. There must be a number of other factors that correlate with the observed salinities that could also explain the differences. I also would encourage caution with statements encouraging oyster aquaculture close to river mouths, as many oyster farmers have suffered from negative consequences from this proximity.

\section{Score Card}

Presentation

4.3

Is the article written in clear and proper English? (30\%)

Is the data presented in the most useful manner? $(40 \%)$

Does the paper cite relevant and related articles appropriately? (30\%)

Does the title suitably represent the article? (25\%)

Does the abstract correctly embody the content of the article? (25\%)

Does the introduction give appropriate context? (25\%)

Is the objective of the experiment clearly defined? (25\%)

\section{Analysis}

Does the discussion adequately interpret the results presented? (40\%)

Is the conclusion consistent with the results and discussion? (40\%)

Are the limitations of the experiment as well as the contributions of the experiment clearly outlined? $(20 \%)$ 